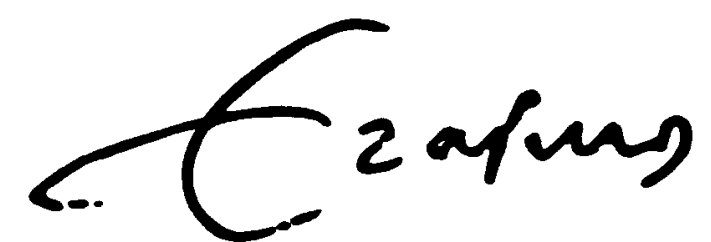

\title{
Living Apart Together in Europe
}

Jean-Pierre van Aubel \& Frans K.M. van Nispen

Erasmus University of Rotterdam

School of Social Sciences

Department of Public Administration

P.O. Box 1738

3000 DR Rotterdam

The Netherlands

Phone: +31 10-408.2131

Fax: +31 10-408.9099

E-mail: vannispen@fsw.eur.nl

David B. Audretsch \& Charles F. Bonser [eds.],

Globalization and Regionalization: Challenges for Public Policy,

Kluwer Academic Publishers,

Boston, Dordrecht, London 2002 


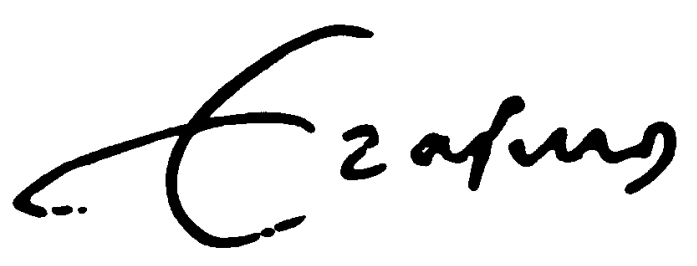

\title{
Living Apart Together in Europe
}

\author{
Jean-Pierre van Aubel \& Frans K.M. van Nispen ${ }^{1}$
}

\section{Introduction}

A decade ago Alice Rivlin issued a new book in which she calls for a revival of the American dream that is 'a democratic political system in which most people feel that they can affect public decisions and elect officials who will speak for them' [Rivlin 1992, p. 1]. The original idea had been faded due to a process of centralization. In the early days, called dual federalism, both levels of government were relatively small, but the power was with the states [1789-1933]. The activities of both levels government expanded during the depression years, but more of the federal government creating a situation of cooperative federalism [1933-1980]. The drive for centralization peaked in the early 80 s and power began shifting back to the states, generating a system of competitive federalism [Shannon \& Kee 1989]. She calls for a division of the job, though two previous attempts to sort out responsibilities under the label of new federalism did not work out [Rivlin 1992, p. 82-84]².

A couple of months ago Joschka Fischer, the German minister of Foreign Affairs articulated his European dream, calling for a specification of the 'Finalität', that is the ultimate goal of the process of European integration. It came at a moment that Europe is challenged by two conflicting developments - globalization and localization - labeled by Tom Courchene as 'glocalization' [Watts 1994].

1. The authors are both affiliated with the Erasmus University of Rotterdam, The Netherlands. We're indebted to Johan Weggeman did a survey of the literature on federations as part his Masters thesis [Weggeman 1997].

2. The Nixon administration launched a plan to return power to the states by cutting the number of categorial grants and providing federal aid to the states with fewer strings. The Reagan administration has proposed a series swaps to sort out the federal and state roles and to reduce the number of categorial grants. 


\section{The European dream}

The F-word is back about 10 year after 'Black Monday', September 30, 1991, when a proposal of the Dutch presidency for the creation of a political union was turned down by the other member states. A couple of months ago Joschka Fischer, the German minister of Foreign Affairs, speaking personally at the Humboldt Universität in Berlin, has launched a plea for the establishment of a political union modeled to the German federation. He envisions a three-stages missile. The first step in the direction of a federation should be an intensification of the cooperation between the European member states by the creation of a group of front-runners ${ }^{3}$, called 'Européens de l'euro', sharing a more or less similar view on the ultimate goal of the process of European integration:

'La seule option réaliste, alors, est que l'integration soit réalisée par les pays qui en ont la volonté politique et dont les conditions économiques et sociales sont presque identiques. En ce moment, tous ces pays appartiennent à la zone euro, dont la population dépasse déjà celles des Etats-Unis' [Giscard d'Estaing \& Schmidt 2000]'.

The establishment of a 'gravity-center' should comprise the second step, leading to a European constitution, a president elected by the population, a government and a strong parliament of two chambers [Fischer 2000a]:

'Ein möglicher Zwischenschritt hin zur Vollendung der politischen Union könnte dann später die Bildung eines Gravitationszentrum sein. Eine solche Staatengruppe würde einen neuen europäischen Grundvertrag schließen, den Nukleus einer Verfassung der Föderation. Und auf der Basis dieses Grundvertrages würde sie sich eigene Institutionen geben, eine Regierung, die innerhalb der EU in möglichst vielen

3. A similar proposal has been put forward before by Jacques Delors, former chairman of the European Commission, talking about a treaty of the founding fathers within the treaty.

4. The former political leaders of France and Germany, co-president of the Committee for the Monetary Union of Europe, refer to the founding fathers. 
Fragen für die Mitglieder der Gruppe mit einer Stimme sprechen sollte, ein starkes Parlament, einen direkt gewählten Präsidenten. Ein solches Gravitationszentrum müsste die Avantgarde, die Lokomotive für die Vollendung der politischen Integration sein und bereits alle Elemente der späteren Föderation umfassen' [Fischer 2000a].

The third step should complete the process of integration by the establishment European federation. In a speech for an audience of students at Georgetown University in Washington, he underscored once again confederation [read: intergovernmental cooperation] should not work in a European Union with 25 up to 30 member states [Fischer 2000b].

Surprisingly, the speech of Joschka Fischer triggered hardly any debate in the other member states with the clear exception of France ${ }^{5}$, that after all has to loose the most because Brussels may be seen as an appendage of Paris and of the French political élite [Siedentop 2000, p. 113]. The speech of Joschka Fischer was counterbalanced by the French president Jacques Chirac during a television interview. At face value they seem to agree, but a closer look reveals a fundamentally different view, that is in line with the French tradition of 'étatism'. He turned out to be not very amused by the idea of a federation:

\section{'Nous ne voulons pas des Etats-Unis d'Europe mais d'une Europe unie des Etats' [Chirac as quoted in Chayette 2000] ${ }^{6}$.}

He referred to a statement of former president Charles de Gaulle who had a Europe des états in mind [De Gaulle 1962, p. $407^{7}$. In a speech during his visit at the German Bundestag in Berlin he addressed the mainly Anglo-Saxon nightmare that the process

5. Only the Belgium prime minister Guy Verhofstadt openly welcomed the formulation of the ultimate goal for the process of European integration in a speech for the European Policy Centre, a think tank located in Brussels. Note that the word federation does not figure in his vocabulary.

6. He has repeated this view in a television interview on July 14, 2000 [Quartorze Juillet].

7. The exact quote has triggered a debate. Some claim that Charles de Gaulle referred to a 'Europe des nations', while others are quoting Charles de Gaulle as talking about a 'Europe des patries' [Siedentop 2000, p. 137], which he has denied explicitly [Droit 1965]. Note that the Jacques Delors, former president of the European Commission, is now talking about a Fédération des Nations Etats [Le Boucher \& Zecchini 2000]. 
of European integration would not result in a superpower, but in a superstate [Thatcher 1988; Blair 2000]:

'Ni vous [the German government, JPvA/FvN] ni nous [the French government, JPvA/FvN] n'envisageons la création d'un super Etat européen qui se substituerait à nos Etats nations et marquerait la fin de leur existence comme acteurs de la vie internationale. Nos nations sont la source de nos identités et de notre enracinement. La diversité de leurs traditions politiques, culturelles et linguistiques est une forces de notre Union. Pour les peuples qui viennent, les nations resteront les premières référence' [Chirac 2000].

However, he was sympathetic to the proposal to create a system of more velocities, but had a preference for a more informal group of pioneers [Chirac 2000]. They both agreed that principle of subsidiarity would remain in the heart of the European constitution.

In addition, the French prime-minister Lionel Jospin, supported by his minister of Finance, Laurent Fabius, used the opportunity of the French presidency to plea for a broader mandate of the Euro-11 by transferring the main responsibility for the antiinflation policy from the ECB to the Euro-11 that has become the Euro-12 recently thanks to the entry of Greece and is meeting as the Eurogroup since the French presidency [see below].

\section{What are they dreaming of?}

One may question what a federation is all about. First of all a distinction has to be made between a federation and a confederation ${ }^{8}$ as well as lighter forms of cooperation. A state is rooted in representation, defined as a mix of territorial and functional constituency which may be fixed as well as variable [Schmitter 1996]. A federation is constituted by a constituency that is fixed in both regards.

8. In contrast to federation, there is no need to create supra-national institutions in a confederation. 
Figuur 1: $\quad$ A Typology of Modern Polities

\begin{tabular}{|l|c|c|}
\hline Functional & Verritorial & Fixed \\
\hline Variable & Condominio & Consortio \\
\hline Fixed & Confederatio & Stato/Federatio \\
\hline
\end{tabular}

Source: Schmitter 1996

The classification of Schmitter is not very helpful when it comes to the distinction between a federation and a unitary state since they are both placed in the same category. A unitary state to begin with is often associated with a central government in charge of the authoritative allocation in different functional domains being congruent with a specific and unique territory [Schmitter 1996, p. 27]. The primary characteristic of a federation is a division of power between the central and regional government on a territorial basis [Riker 1964, p. 11] ${ }^{9}$. On top, a few secondary characteristics can be identified like a written constitution, a bicameral legislature and a supreme court to protect the constitution [Lijphart 1984; Lijphart 1999].

The American federation as described by Alexis de Tocqueville on his trip through America [1830-1831] is often seen as the pure federation:

'The prerogatives of the federal government were therefore carefully defined and it was declared that everything that was not comprised in that definition returned to the prerogatives of the state governments. Thus the state governments remained the common rule; the federal government was the exception' [De Tocqueville 2000, p. 107-108].

9. The definition of William Riker is critized by Vincent Ostrom because of the constitution as the one and only yardstick as well as the restriction to two layers of government. A federation has be democratic in his view [Ostrom 1974]. 
In fact, the division of power has moved away from the original idea of the founding fathers. The two layers of government are not independent, but rather interdependent, nowadays referred to as dual vs. cooperative federalism [Landau 1974, p. 174]. It constitutes the main distinction between the American and German federation [Scharpf 1988, p. 242], though the American federation has inspired the current German constitution [Siedentop 2000, p. 174] which is marked by what is called 'Politikverflechtung' in Germany [Scharpf et al. 1976] ${ }^{10}$.

The vast majority of the European member states can be qualified as a unitary state. Only Austria, Belgium and Germany can be seen as a federation ${ }^{11}$ though the typology does not count for semi-federal states like Spain and sociologically federal states like The Netherlands ${ }^{12}$.

Figuur 2: $\quad$ A Categorization of European Member States

\begin{tabular}{|l|c|c|}
\hline & Centralized & Decentralized \\
\hline Federation & Austria & Belgium, Germany \\
\hline Unitary State & $\begin{array}{c}\text { France, Greece, Ireland, } \\
\text { Italy, Luxembourg, } \\
\text { Portugal }\end{array}$ & $\begin{array}{c}\text { Denmark, Finland, } \\
\text { Sweden }\end{array}$ \\
\hline
\end{tabular}

Source: Lijphart 1984

A federation is often associated with decentralization, but the opposite is true for the road to a federation as is shown the process of European integration. In most cases federalization means centralization, that is the transfer of authority and responsibility to a higher level of government. However, centralization is not the only way to create a federation as might be illustrated by the developments in Belgium that has launched

10. The cooperation might be horizontal as well as vertical. In the last case regional governments are only involved in the implementation of a policy program [Scharpf 1978, p. 23-26].

11. A survey of Jean Blondel shows the existence 16 federations in the world [Blondel 1995], while Elazar comes 21 federations [Elazar 1995].

12. Strangely enough The Netherlands is often referred to as a decentralized unitary state. 
a comprehensive program of decentralization, moving away from a semi-federation towards a full federation [1993],

\section{A United States of Europe?}

The proposal of Joschka Fischer for a federation was turned down at an informal meeting of the ministers of Foreign Affairs of the European member states in Evianles-Bains, France. The minister of Foreign Affairs of Spain, Josep Piqué i Camps, argued that it made no sense to talk about a political union as long as the outcome of the experiment with the economic and monetary union and the single currency is not clear. A positive experience may have spill over effect on the willingness to cooperation and integration in other areas [Bekkers 1995, p. 6]. However, we feature all kinds of developments that point towards a federation. The work on the secondary characteristics of a federation is going on, applying once again the method of 'fait accompli'. The heads of state and prime-ministers of the European member states agreed at the Nice summit on a Charter of Fundamental Rights that could function as a steppingstone for a written European constitution that includes a clear-cut division of power. The British prime-minister Tony Blair has echoed a plan for the establishment a European senate introducing bi-cameralism [Blair 2000] and a European court is already in place. The point is that these new institutions may help to create the consensus needed to create a federation, but that such a consensus cannot be reached overnight. It might take decades, probably generations. He concludes that a federation is the right goal for Europe, but that Europe is not ready for a federation [Siedentop 2000, p. 231].

Besides, there is nothing new under the sun with regard to the decision to get along with enhanced, flexible cooperation at the Nice summit [2000] as might be illustrated by the Schengen agreement $[1985]^{13}$ and, more clearly, the Maastricht treaty [1991] that gave birth to the Economic and Monetary Union. A number of new supranational institutions has been established as part of the Economic and Monetary Union [EMU], notably the European Central Bank [ECB] located in Frankfurt,

13. The agreement is recently expanded to Norway and Iceland, that do not belong to the European Union. 
Germany, pursuing a joint monetary policy in order to avoid inflation in the European member states ${ }^{14}$. In addition, a number of criteria were set for participation in the EMU, like a reduction of the budget deficit, the public debt, the interest rates and last, but not least the inflation rates ${ }^{15}$. Furthermore, a procedure was established for the reduction of excessive budget deficits to attain and maintain price stability ${ }^{16}$. In the end 11 out of 15 countries qualified for the EMU, though only a few states were meeting all the criteria. Notably, Belgium and Italy were running a public debt far above the reference value of $60 \%$ of GDP. Only Greece was disqualified for participation. The British and Danish government called for an opt-out, later followed by Sweden ${ }^{17}$, mainly forced by the public opinion giving way to a system of various speeds 'avant la lettre'.

The discussion about the first president as well as the location of the ECB at the Amsterdam summit [1997] revealed a fundamental different view on the appropriate role of the new institution [Siedentop 2000]. In line with the tradition of 'étatism' the French government questioned the independent position of the ECB, which may be seen as a characteristic of a federation: the five central banks with the greatest independence all operate in federal systems [Lijphart 1999, p. 241] ${ }^{18}$. It put forward a proposal to create a political watchdog, called Euro-X at that time. It was watered down to an informal meeting at the price of a Resolution on Growth and Employment that provides a framework for the fight against unemployment ${ }^{19}$. The Eurogroup is now meeting in advance of the meeting of the Council of the European Union in the composition of the ministers of Finance of the European member states. The first item on the agenda of the so-called Economic and Financial Affairs Council

14. The ECB is a part of the European System of Central Banks [ESCB] that further consists of the national banks of the European member states.

15. In addition two prerequisites have to be met: the national central bank has to be independent and the national currency of the candidate has to be part of the Exchange Rate Mechanism [ERM] for at least two years.

16. In a protocol the reference value was set at $3 \%$, later further reduced to $0 \%$ of GDP. The heads of state and the prime ministers of the Europe member states committed themselves at the Amsterdam summit to a budget position 'close to balance or in surplus'. Note that almost at the same time an amendment to the American constitution was turned down to ensure a balanced budget at the federal level.

17. At the time of the Maastricht treaty Sweden did not yet participate in the process of European integration. It has joint the group together with Austria and Finland in 1995.

18. He mentions Austria, Canada, Germany, Switzerland and the US.

19. In retrospect it is strange that the rate of unemployment does not belong to the criteria participation in the EMU, especially because the fight against unemployment was at the middle of the debate at the eve of the Maastricht summit. The performance of some European member states, notably Finland and Spain, is changing drastically if unemployment is added as a yardstick. 
[ECOFIN] after the opening of meeting is to fill in the opt-outs about the outcome of the Eurogroup session.

The last addition so far is the decision to create a Eurocorps of about 60,000 troups that may be deployed within 60 days and may be sustained for at least a year to fulfill the so-called Peterburg mission. However, the process of integration will never end in a United States of Europe as Joschka Fischer has admitted recently in response to Belgian lawmakers:

'Europe will never be a federation on the U.S. model because it will never have a homogeneous national population. It is made up of different languages, cultures. Building up a U.S.-style system is therefore an illusion' [Fischer 2000c].

As a result, mobility of labor will be less than in the American context. Besides, there is still considerable degree of vitality in the European member states [Berting \& Heinemeijer 1995, p. 56].

Finally, subsidiarity will always play a major role in the European situation ${ }^{20}$. It means that a decision should be taken as closely as possible to the citizens [Bekkers et al. 1995, p. 2], that is by the national member states unless the decision power is transferred to one of the supranational institutions ${ }^{21}$. The outcome of the process of European integration, either it is called a federation, a confederation or a construction 'sui generis' [Lubbers as quoted in Benschop 2000], is as such in line with the striking characterization of Alexis de Tocqueville of the original idea of the American federation.

20. The principle of subsidiarity is laid down in a protocol to the Amsterdam treaty.

21. The division of power may be laid down in a 'Kompetenz-katalog', a register that constitutes the authority of both levels of government. 


\section{Literature}

Bekkers, Victor J.J.M., H.T.P.M. \& G. Leenknegt [eds.], Subsidiariteit en Europese integratie. Een oude wijsheid in een nieuwe context [Subsidiarity and European Integration. An Old Wisdom in a New Context], W.E.J. Tjeenk Willink, Zwolle 1995.

Benschot, Dick, Inleiding over de uitbreiding van de Europese Unie [Introduction on the enlargement of the European Union, Europa Salon, Clingendael, 's-Gravenhage 28 juni 2000.

Berting, Jan \& Willem F. Heinemeijer, 'Europe' as a multilevel problem, in: Keebet van BendaBeckman \& Maykel Verkuyten [eds.], Nationalism, Ethnicity and Cultural Identity in Europe, European Research Centre on Migration and Ethnic Relations, Utrecht 1995.

Blair, Tony, Europe's Political Future, speech delivered at the Polish Stock Exchange, Warsaw, October 6, 2000.

Blondel, Jean, Comparative Government. An Introduction, Prentice Hall/Harvester Wheatsheaf, London 1995 [ $2^{\text {nd }}$ edition].

Chayette, Silvie, Extraits de l'allocution de Jacques Chirac [Extracts from a Speech by Jacques Chirac], Le Monde 14 juillet 2000.

Chirac, Jacques, Notre Europe, discours prononce devant le Bundestag, Reichstag, Berlin, June 27, 2000.

Conlan, Timothy, From New Federalism to Develution. Twenty-Five Years of Inter-governmental Reform, Brookings Institution Press, Washington 1998.

De Gaulle, Charles, Conférence de press [press conference] May 15, 1962, in: Charles de Gaulle, Discours et messages, Plon, Paris 1970, Tome 4 [1962-1965].

De Tocqueville, Alexis, Democracy in America, The University of Chicago Press, Chicago 2000.

Droit, Michel, Entretien avec Charles de Gaulle [Interview with Charles de Gaulle] 14 décembre 1965, in: Charles de Gaulle, Discours et messages, Plon, Paris 1970, Tome 4 [1962-1965].

Elazar [ed.], Daniel J., The Federal Polity, Center for the Study of Federalism, Philadelphia 1974

Elazar, Daniel J., From Statism to Federalism: A Paradigm Shift, Publius 1995 [vol. 25], nr. 2, p. 5-18.

Fischer, Joschka, Vom Staatenverbund zur Föderation - Gedanken über die Finalität der europäischen Integration, Rede in der Humboldt-Universität in Berlin am 12 Mai 2000a.

Fischer, Joschka, Towards a New Transatlantic Partnership: The United States, Germany and Europe in an Era of Global Challenges, Herbert Quandt lecture, Georgetown University, September $15,2000 \mathrm{~b}$.

Fischer, Joschka, EU Won't Be A Single State Like U.S., International Herald Tribune November 15, 2000c.

Giscard d'Estaing, Valéry \& Helmut Schmidt, La leçon d'Europe [The Lesson of Europe], Le Figaro April 10, 2000 ]

Hénard, Jacqueline, Daniel Vernet \& Roger de Weck, La face-à-face Chevènement-Fischer [Face to Face: Chevènement vs Fischer, Le Monde/Die Zeit, June 21, 2000 [@ Le Monde/Die Zeit]. Landau, Martin, Federalism, Redundancy and System Reliability, in, Elazar, op. cit. 1974, p. 173-196. 
Le Boucher, Eric \& Laurent Zecchini, Jacques Delors critique la stratégie d'élargissement de l'Union [Jacques Delors critizes the enlargement stategy of the (European) Union], Le Monde 19 janvier 2000.

Lijphart, Arend, Democracies. Patterns of Majoritarian and Consensus Government in Twenty-One Countries, Yale University Press, New Haven/London 1984.

Lijphart, Arend, Patterns of Democracy. Government Forms and Performance in Thirty-Six Countries, Yale University Press, New Haven/London 1999.

Ostrom, Vincent, Can Federalism Make a Difference?, in: Elazar, op. cit., 1974, p. 197-238.

Ostrom, Vincent, The Meaning of American Federalism. Constituting a Self-Governing Society, ICS Press, San Francisco 1991.

Riker, William H., Federalism: Origin, Operation, Significance, Little, Brown and Co, Boston 1964.

Rivlin, Alice, Reviving the American Dream. The Economy, the States and the Federal Government, The Brookings Institution, Washington 1992.

Scharpf, Fritz W., Bernd Reissert \& Fritz Schnabel, Politikverflechtung: Theorie und Empirie des kooperativen Föderalismus in der Bundesrepublik [Joint Decision Making. Theory and Practice of Cooperative Federalism in Germany], Scriptor, Kronberg 1976.

Scharpf, Fritz W., Die Theorie der Politikverflechtung. Ein kurzgefaßter Leitfaden [The Theory of Joint Decision Making], in Joachim Jens Hesse [ed.], Politikverflechtung im Föderativen Staat [Joint Decision Making in a Federation], Nomos, Baden-Baden 1978, p. 21-31.

Scharpf, Fritz W., The Joint-Decision Trap: Lessons From German Federalism and European Integration, Public Administration 1988 [vol. 66], nr. .., p. 239-278.

Schmitter, Phillippe C., Some alternative futures for the European policy and their implications for European public policy, in: Yves Mény, Pierre Muller \& Jean-Louis Quermonne [eds.], Adjusting to Europe The Impact of the European Union on National Institutions and Policies, Routledge, London 1996, p. 25-40.

Shannon, John \& James E. Kee, The rise of Competitive Federalism, Public Budgeting and Finance 1989 [vol. 9], issue 4, p. 5-20.

Siedentop, Larry, Democracy in Europe, Allen Lane, The Penguin Press, London etc. 2000.

Thatcher, Margaret, Britain and Europe, speech delivered at the College of Europe, Bruges, Belgium, September 20, 1988.

Van Nispen, Frans K.M., The F-word is Back!, preface to Budgeting for the European Monetarian Union, Erasmus University of Rotterdam 2000, p. 4.

Verhofstadt, Guy, A Vision for Europe, speech to the European Policy Centre, Brussels, September 21, 2000.

Watts, Robert L., Contemporary views on federalism, in: B. de Villiers [ed.], Evaluating Federal Systems, Martinus Nijhoff, Dordrecht 1994.

Weggeman, Johan, Consociatie en federatie. Een literatuurstudie naar hun onderlinge verhouding [A Survey of the Literature on the Interrelation Between Consociation and Federation], Rijksuniversiteit Leiden, 1997. 
Weggeman, Johan, Federalisme-onderzoek: nevels en nut, Bestuurskunde [Research on Federalism: Smoke and Utility], Bestuurskunde 1998 [jrg. 7], nr 8, p. 368-378. 